\title{
The moderating effect of employee motivation on workplace surveillance and employee engagement amongst employees at the Zimbabwe Revenue Authority
}

\begin{tabular}{|c|c|}
\hline \multicolumn{2}{|c|}{$\begin{array}{l}\text { Authors: } \\
\text { Fidelis P. Tsvangirai }{ }^{1} \\
\text { Willie T. Chinyamurindi }\end{array}$} \\
\hline \multicolumn{2}{|c|}{$\begin{array}{l}\text { Affiliations: } \\
{ }^{1} \text { Department of Industrial } \\
\text { Psychology, University of Fort } \\
\text { Hare, Alice, South Africa }\end{array}$} \\
\hline \multicolumn{2}{|c|}{$\begin{array}{l}{ }^{2} \text { Department of Business } \\
\text { Management, University of } \\
\text { Fort Hare, East London, } \\
\text { South Africa }\end{array}$} \\
\hline \multicolumn{2}{|c|}{$\begin{array}{l}\text { Corresponding author: } \\
\text { Willie Chinyamurindi, } \\
\text { chinyaz@gmail.com }\end{array}$} \\
\hline \multicolumn{2}{|c|}{$\begin{array}{l}\text { Dates: } \\
\text { Received: } 27 \text { July } 2018 \\
\text { Accepted: } 12 \text { Sept. } 2018 \\
\text { Published: } 23 \text { Apr. } 2019\end{array}$} \\
\hline \multicolumn{2}{|c|}{$\begin{array}{l}\text { How to cite this article: } \\
\text { Tsvangirai, F.P., \& } \\
\text { Chinyamurindi, W.T. (2019). } \\
\text { The moderating effect of } \\
\text { employee motivation on } \\
\text { workplace surveillance and } \\
\text { employee engagement } \\
\text { amongst employees at the } \\
\text { Zimbabwe Revenue Authority. } \\
\text { SA Journal of Human Resource } \\
\text { Management/SA Tydskrif vir } \\
\text { Menslikehulpbronbestuur, } \\
\text { 17(0), a1106. https://doi.org/ } \\
\text { 10.4102/sajhrm.v17i0.1106 }\end{array}$} \\
\hline \multicolumn{2}{|c|}{$\begin{array}{l}\text { Copyright: } \\
\text { (C) 2019. The Authors. } \\
\text { Licensee: AOSIS. This } \\
\text { is licensed under the } \\
\text { Creative Commons } \\
\text { Attribution License. }\end{array}$} \\
\hline \multicolumn{2}{|l|}{ Read onlin } \\
\hline 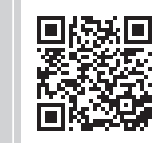 & $\begin{array}{l}\text { Scan this QR } \\
\text { code with your } \\
\text { smart phone or } \\
\text { mobile device } \\
\text { to read online. }\end{array}$ \\
\hline
\end{tabular}

Orientation: The study took place at the Zimbabwe Revenue Authority (ZIMRA), an organisation noted to be undergoing varying challenges because of the macro-environmental issues in Zimbabwe.

Research purpose: The study examined the moderating effect of employee motivation on workplace surveillance and employee engagement amongst employees at ZIMRA.

Motivation for the study: Calls exist for studies that explore how organisations can assist their employees, especially within contexts deemed to be difficult to operate in.

Research approach/design and method: This study adopted the positivist research philosophy and used the quantitative research approach. A self-administered questionnaire was sent to 364 respondents using an online survey. The study utilised the principles of structural equation modelling in analysing the data.

Main findings: The results are twofold. Firstly, the results of the study show the existence of a relationship between workplace surveillance and employee engagement. Secondly, this relationship is partially moderated by employee motivation.

Practical/managerial implications: There is need for ZIMRA management to involve employees when making decisions on issues about workplace surveillance. Such involvement may have an effect on outcomes such as engagement and motivation within the workplace.

Contribution/value-add: The study contributes to the body of knowledge by noting that employee motivation moderates the relationship between workplace surveillance and employee engagement. Thus, the presence of workplace surveillance calls for more investment in employee motivation if employees are to remain engaged with their work.

Keywords: employee motivation; employee engagement; workplace surveillance; Zimbabwe; human resources.

\section{Introduction}

This research examines how the relationship between workplace surveillance and employee engagement is moderated by employee motivation amongst Zimbabwe Revenue Authority (ZIMRA) employees. Whenever there is an employment contract, employees will be monitored in a certain way, and with the advent of modern technology, workplace surveillance is on the rise (Steinfeld, 2017). According to Zameer, Ali, Nisar and Amir (2014), workplace challenges and organisational problems are not always caused by clients or customers but also by employees.

Employee engagement, according to Shaheen and Farooqi (2014), can be measured in three dimensions, namely, cognitive, physical and emotional. Allen (2014) concluded that a worker who exhibits high levels in all three dimensions outlined by Shaheen and Farooqi (2014) is deemed to be highly engaged in their work. Employee engagement, according to Kahn (1990), is an old and widely researched concept but its conception as argued by Sibanda (2016) is an emerging and widely researched topic.

According to Chang and Teng (2017), motivation is the desire to accomplish individual and organisational goals. Mafini, Surujlal and Dhurup (2013) concluded that in most cases, highly motivated employees are also engaged in their jobs and they get satisfaction from this. 
Sarwar and Abugre (2013) opined that organisational success thrives through employee motivation and managers need to properly manage employee motivation.

Rosenblat, Kneese and Danah (2014) noted that employers need to invest in workplace surveillance to reduce pilferage, increase productivity and avoid leakage of confidential information. Moussa (2015) reiterates that employee motivation can be affected in a negative way by workplace surveillance if such a system is not properly implemented and managed. According to Allen, Walker, Coopman and Hart (2007), workplace surveillance refers to mechanisms adopted by management at work to ensure that all movements by employees are being seen. Yerby (2013) also describes workplace surveillance as a system of ensuring that the employer is observing employees' actions and movements at work. Yamoah (2014) refers to workplace surveillance as the act of ensuring that all employees are working with tight supervision from management. Zuboff (2015) reiterates that workplace surveillance is a management approach to make sure that employees apply themselves fully to their work during working hours without engaging in non-work-related activities. Such surveillance can be done through mediums like logbooks, electronic or physical checking by supervisors.

\section{Background to the study}

Yamoah (2014) concluded that service delivery in public service organisations is hampered by low levels of employee engagement. As a parastatal that was formed and mandated to operate feeding into the fiscus, in terms of Chapter 23:11 of the Zimbabwe Revenue Authority Act in 2001, ZIMRA needs to deliver against all odds. Research conducted by Mafini and Dlodlo (2014) in South African government departments on poor service delivery concluded that public service employees have low levels of engagement and this affects how they do their work.

Further, research has found that, generally, organisations in Southern Africa have poor performance, which emanates from disengaged and demotivated employees (Mafini, 2015). Because of continued congestion and slow turnaround times at Zimbabwe's main border posts, ZIMRA's motto denoting that the organisation is there to serve the public is far from being realised (Muleya, 2014; Sibanda, 2016). Workplace surveillance and employee engagement are some of the reasons proffered in discussions on causes of poor service delivery in public organisations (Yamoah, 2014).

A lifestyle audit was conducted by ZIMRA in 2016 to ascertain if there were any employees who could have attained their wealth fraudulently (Vinga, 2017). This audit was not well received by employees, who felt that the exercise had a negative impact on their motivation levels (Ncube, 2016). Research by Saltson and Nsiah (2015) reiterated that it is important for organisations to ensure that they make business decisions that do not derail employee motivation lest employees sabotage the organisation. Low remuneration at border posts was found to be a leading factor in causing low employee engagement amongst ZIMRA employees, making them susceptible to corruption (Huni, 2016; Mundia, 2014). Muleya (2014) went on to say that this system is effective when used by engaged employees, who can shrug off corruption advances, but with the current low levels of employee engagement at the border posts, the system is not living up to its purpose.

Research shows that a negative relationship exists between organisational behaviour and workplace surveillance (e.g. Moussa, 2015; Ncube, 2016; Samaranayake \& Gamage, 2012; Townsm \& Cobb, 2012; Yerby 2013; Zachary, 2013). According to ZIMRA (2016), in 2016, the organisation put in place surveillance cameras worth $\$ 600000$ at the Beitbridge border post, where most fraudsters and ZIMRA employees are caught in illegal acts. Despite these investments, empirical research is needed that continues to explore the relationships between psychological variables and interventions such as workplace surveillance. Uniquely, this study examined the moderating effect of employee motivation on workplace surveillance and employee engagement amongst employees at ZIMRA. This answers calls for studies of this nature (Tomczak, Lanzo, \& Aguinis, 2018).

The authors note that other than being the Zimbabwe customs environment and hard economic environment, the present study focuses on ZIMRA because it sought to obtain information pertaining to the slow turnaround time at the border posts, which is a sign of poor service delivery that invites public backlash. ZIMRA's mandate has a great impact on the country's gross domestic product and the organisation needs to deliver results to the fiscus. Public organisations consequently often face the criticism that they do not deliver the quality of service expected (Allen, 2014). It is important to invest much in employee motivation and employee engagement for maximum organisational performance (Maduka \& Okafor, 2014). This context was critical in assisting this study in investigating whether workplace surveillance enhances or impedes employee engagement and whether employee motivation moderates the relationship between the two variables. Mundia (2014) concluded that ZIMRA's skewed and poor remuneration is tainting employees' levels of engagement, which is compounded by the heavy presence of workplace surveillance at all the border posts. Sibanda, Muchena and Ncube (2014) added that it is difficult for employees to engage in their work and feel motivated when working under such bad conditions.

This study is necessary in Zimbabwe in that it ushers in possible solutions to manage the subdued economy of the country through human resources. The parliament of Zimbabwe (2017) referred to a report by the Industrial Psychology Consultancy that noted that employee engagement amongst Zimbabwean parastatals in 2016 was at $40 \%$, showing that $60 \%$ of employees in the parastatals are not engaged in their work. The rise of the unemployment rate in Zimbabwe increased poverty levels to $72 \%$, putting most citizens into abject poverty. The World Bank (2017) then 
concluded that this is why the United Nations Human Development Index placed Zimbabwe at number 173 out of a total of 187 countries, because the economy had literally collapsed. Firstly, the country is experiencing a high labour turnover, averaging 19\% per year because of an unstable economic setting (Murongazvombo, 2015). Secondly, within this high labour turnover, there is need for employers to find strategies not only to keep their employees motivated and engaged but also to monitor how they work.

\section{Literature review}

This section focuses on discussing the literature around the three research constructs under this study. The discussion shows the relationship that exists amongst the three constructs guided by the literature. The literature reviewed under this section to ascertain the relationship that exists amongst these variables assisted the researchers in coming up with the study hypotheses.

\section{Employee engagement and employee motivation}

According to Ryan (2017), a universal definition for employee engagement cannot be ascertained because the concept borders around three main components, namely cognitive, emotional and behavioural. This complexity of having a universal definition for employee engagement was also echoed by Ruck, Welch and Menara (2017), who concluded that because employee engagement hinges on cognitive, emotional and behavioural components, a universal definition cannot be proffered.

DeVaroa, Nan Maxwell and Morita (2017) conducted a study that focused on employee trust, employee engagement and employee motivation. The study found that employees who were disengaged and demotivated had no trust in their management and were ready to resign if they got the opportunity. An investigation on the relationship between employee engagement, employee motivation and employee absenteeism was conducted at the Allied Bank of Pakistan by Khan and Iqbal (2013). The study concluded that employee motivation and employee engagement positively relate to the another.

Organisational performance usually suffers when employees are dissatisfied at the workplace, because such dissatisfaction leads to low engagement and low motivation (Mafini \& Dlodlo, 2014). A study conducted by Vilnai-Yavetz and Levina (2018) concluded that employees get engaged and motivated to do their work when they get support from the organisation. The study also noted that employee motivation positively relates to employee engagement regardless of the management approach. According to Mafini and Dlodlo (2014), empirical evidence on how employee motivation and engagement is affected by stringent management approaches is lacking in most developing countries. The lack of such empirical evidence in third world countries also motivated this study to close this gap. This literature has shown that it can be expected that employee motivation positively relates to employee engagement. Because of this, the following hypothesis was formulated:

$\mathbf{H}_{1}$ : There is a positive relationship between employee engagement and employee motivation.

\section{Workplace surveillance and employee engagement}

Cordella and Cordella (2017) found that a safe and efficient working environment is mainly attained when an organisation pays close attention to employee activities during working hours. However, it is unfortunate that in most cases such workplace surveillance measures are installed without employee input, and this negatively affects employee engagement (Rosenblat et al., 2014). A study by Bakar (2013) amongst the Malaysian financial sector was conducted to ascertain the factors that negatively impact employee engagement and satisfaction in the workplace. This study found that employees do not like working under a context of surveillance, noting that it makes them feel untrusted.

Research has also found that employees do not like workplace surveillance measures because they make them feel that their rights are being infringed upon, ultimately leading to disengagement from work (Moussa, 2015). Workplace trust is negatively affected in an organisation that uses workplace surveillance and in most cases organisational success suffers from a disengaged workforce (Rosenblatt et al., 2014). The impact of workplace surveillance on employee engagement has not yet been researched in Zimbabwe. Based on the mentioned literature, it can be expected that employee engagement and workplace surveillance negatively relate. The following hypothesis was formulated:

$\mathbf{H}_{2}$ : There is a negative relationship between employee engagement and workplace surveillance.

\section{Employee motivation, employee engagement and workplace surveillance}

Technology advancements have brought an increase in the use of workplace surveillance in the last two decades, removing such surveillance duties from the supervisors who used to observe and record employee actions manually (Mayer, Viviers, \& Tonelli, 2017). Technological advancement has made it easy for organisations to observe and survey employee actions every second while they are working without physically observing them. Technology is useful in gathering information that is necessary for performance evaluation, data analysis and decision-making; most employees understand this function of surveillance and such surveillance makes them feel motivated (Gawke, Marjan, Gorgievski, \& Bakker, 2017). Research by Rosenblat et al. (2014) in the United States (US) found that data and word processing jobs are amongst the jobs that are heavily subjected to surveillance in many organisations. The authors also found that such surveillance had no impact on employee engagement and motivation in organisations that invested in employee cognitive engagement. 
A study to ascertain the impact of employee engagement and employee motivation on organisational performance found that employees are not motivated when they are working under surveillance and that it negatively affected their performance and that of the organisation (Shahzadi, Javed, Pirzada, Nasreen, \& Khanam, 2014). The study also found a positive relationship between employee motivation and employee engagement. According to Lopez-Valeiras, GomezConde and Lunkes (2017), such a finding points to the fact that employee motivation positively moderates the relationship that exists between workplace surveillance and employee engagement. The authors added that this shows that employee motivation positively impacts on employee engagement and ultimately the performance of the organisation, regardless of the presence of workplace surveillance. However, workplace surveillance negatively relates to employee motivation (Desprochers \& Roussos, 2001).

According to Fuchs (2013), capitalists who want to ensure that employees waste no working time mostly use workplace surveillance. The study also concluded that such surveillance employed with a capitalist mentality negatively impacts on employees and usually leads to high rates of absenteeism, demotivation, low morale, high labour turnover and employee disengagement. Fuchs (2013) highlights that there is heavy use of workplace surveillance in the capitalist economy when compared to other economic systems. A study by Steinfeld (2017) concluded that investment by management in employee motivation gives positive results in organisational performance, and the use of workplace surveillance without proper management can negatively affect employee motivation and engagement.

Tomczak et al. (2018) note a trend within the literature (e.g. Patsakis, Charemis, Papageorgiou, Mermigas, \& Pirounias, 2018; Tsakanikas \& Dagiuklas, 2017; Ryan, 2017) indicating that a negative relationship exists between employee motivation and workplace surveillance. This often results in employees devising ways to circumvent the surveillance mechanisms in search of privacy and rights (Yerby, 2013). Further, concern is given to how such workplace surveillance measures also impact on employee morale and ultimately the industrial relations climate in the organisation (Mayer et al., 2017). Based on all of this, it can be expected that employee motivation moderates the relationship that exists between employee engagement and workplace surveillance. The following hypothesis was formulated:

$\mathbf{H}_{3}$ : Employee motivation positively moderates the relationship between employee engagement and workplace surveillance.

Figure 1 depicts a model of the relationship between employee motivation, employee engagement and workplace surveillance.

\section{Research design Research approach}

The study utilised a survey research design and was guided by the positivist research paradigm, which is quantitative

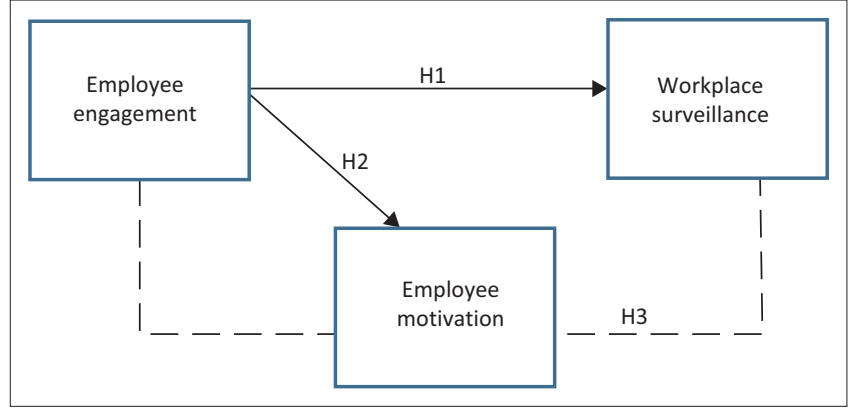

H, Hypothesis.

FIGURE 1: A model of the relationship between employee motivation, employee engagement and workplace surveillance.

and descriptive in nature. The validation of constructed theories was done using this paradigm; such analysis and validation would have been difficult with a qualitative approach. Moreover, this paradigm was adopted because it enables production of information and data that is replicable over a long period of time.

\section{Research participants}

The total population of the study was derived from staff and managers who were based at Zimbabwe's 10 main border posts, managed by ZIMRA, whose overall population size was 4000. Yamani's (1964) formula was used to calculate the ideal sample size because it assists in attaining high accuracy, and a total of 364 responses were given by the formula.

\section{Sampling approach}

The selection of ZIMRA for the study was done on purpose because it manages the entry and exit points in Zimbabwe, where slow turnaround time concerns were raised. Because there are 10 border posts across the country, a census approach was employed to curb bias tendencies while ensuring representativeness. To make sure that the sample size was proportionate to the total population size, stratified random sampling was employed in determining the number of respondents per border post.

\section{Pilot study, validity and reliability of the study instrument}

The study complied with content, construct and face validity. The reliability of the research instrument was measured using the Cronbach's alpha coefficient. Stratified randoms sampling was used in identifying respondents for the pilot study. A number of authors (e.g. Hertzog, 2008; Lackey \& Wingate, 1998; Nieswiadomy, 2002) recommended that a pilot study must be conducted using $10 \%$ of the total population that is poised to participate in the research, and this resulted in 36 respondents out of a total population sample of 364 being used.

\section{Measuring instrument}

The research instrument that was used in data collection is the structured questionnaire, and example items for each research construct together with the original references per construct are given in Table 1 . Table 1 depicts the measuring 
TABLE 1: Reliability statistics of the research instrument.

\begin{tabular}{lll}
\hline Construct & $\begin{array}{l}\text { Previous studies where } \\
\text { scale was used }\end{array}$ & $\begin{array}{l}\text { Cronbach's } \\
\text { alpha coefficient }\end{array}$ \\
\hline Workplace surveillance & $\begin{array}{l}\text { Rietzschel, Slijkhuis and } \\
\text { Van-Yperen (2014) }\end{array}$ & 0.72 \\
Employee motivation & Akafo and Boateng (2015) & 0.79 \\
Employee engagement & Khan and Iqbal (2013) & 0.78 \\
\hline
\end{tabular}

instrument used by this study. The previous research literature guided this study in formulating its research instrument. The research instrument had a total of 82 structured questions on a seven-point Likert scale.

\section{Data collection and analysis procedure}

The respondents were advised not to include their personal details on the questionnaire for anonymity purposes. The objectives and consent form were detailed in a letter that accompanied the questionnaire via SurveyMonkey. To ascertain if respondents would face any difficulties in responding to the questionnaire, the questionnaire was subjected to a pilot study. Stratified random sampling was adopted in identifying pilot study respondents and a total of 26 participated in the pilot study, distributed across all main border posts. The main research data collection was done using SurveyMonkey while the analysis of the conceptual framework and confirmatory factor analysis was done using structural equation modelling (SEM). Data analysis was also performed using the Analysis of Moment Structure software.

\section{Ethical considerations}

Prior to data collection, the researcher sought ethical clearance through the University of Fort Hare Research Ethics Committee (clearance number - CHI221STSV01). The researcher applied for research permission from ZIMRA management.

\section{Results}

This section presents the study results.

\section{Reliability tests}

The internal consistencies of reliability for employee motivation, employee engagement and workplace surveillance was measured in the study. According to Cronbach (1951), research must accept all the Cronbach's alpha values above 0.7 , while the most preferred values are those above 0.8 . The reliability test for the research variables are presented in Table 2.

The data gathered and analysed gave the following Cronbach's alpha values for the research constructs under the study: employee motivation had 0.913, employee engagement had 0.768 and workplace surveillance had 0.765 . These values give an overall Cronbach's alpha coefficient value of 0.778 , depicting a good internal consistency of the questionnaire items for the three constructs. This shows that of the 80 statements listed for the three research constructs, there were none deleted.
TABLE 2: Cronbach's alpha.

\begin{tabular}{lccc}
\hline Variable & $\begin{array}{c}\text { Cronbach's } \\
\text { alpha }\end{array}$ & $\begin{array}{c}\text { Cronbach's alpha based on } \\
\text { standardised items }\end{array}$ & $\begin{array}{c}\text { Number of } \\
\text { items }\end{array}$ \\
\hline $\begin{array}{l}\text { Reliability statistics for } \\
\text { the entire scale }\end{array}$ & 0.778 & 0.811 & 81 \\
$\begin{array}{l}\text { Reliability statistics for } \\
\text { individual constructs }\end{array}$ & & & \\
Workplace surveillance & - & 0.765 & 17 \\
Employee engagement & - & 0.768 & 43 \\
$\begin{array}{l}\text { Employee } \\
\text { motivation }\end{array}$ & - & 0.913 & 21 \\
\hline
\end{tabular}

TABLE 3: Demographic descriptive statistics.

\begin{tabular}{lc}
\hline Variable & Frequency (\%) \\
\hline Gender & 57.5 \\
Male & 42.5 \\
Female & \\
\hline Age & 8.0 \\
26-30 years & 34.5 \\
31-40 years & 37.0 \\
41-50 years & 20.5 \\
50+ years & \\
Level of education & 0.60 \\
A-level & 13.50 \\
Diploma or certificate & 41.60 \\
Bachelor's degree & 41.30 \\
Honour's degree & 3.10 \\
Master's degree & \\
Work experience & 1.80 \\
Less than 3 years & 15.60 \\
4 to 5 years & 38.70 \\
6 to 7 years & 43.90 \\
Over 7 years & \\
Respondent's position & 4.30 \\
Manager & 10.70 \\
Supervisor & 57.80 \\
Officer & 26.00 \\
Worker's union rep & 1.20 \\
Other & \\
\hline
\end{tabular}

\section{Descriptive statistics}

The descriptive statistics denoting work experience, level of education, age, respondent's position and gender are listed in Table 3.

\section{Kaiser-Meyer-Olkin and Bartlett's test}

The Bartlett's test of sphericity value must be statistically significant at $p<0.05$ with a Kaiser-Meyer-Olkin (KMO) value of 0.6 or above to be considered suitable for factor analysis (Pallant 2007). Data suitability for factor analysis is indicated by Bartlett's test of sphericity. Unsuitability of data for factor analysis is indicated by a non-significant $(p>0.05)$ Bartlett's test of sphericity. According to Tabachnick and Fidell (2007), KMO reports the amount of variance in the data that can be explained by the factors and is a measure of sampling adequacy. Table 4 shows the KMO and Bartlett's test values.

Table 4 shows the results of the sphericity test. The KMO value was 0.765 , which exceeded the recommended value of 0.6. The Bartlett's test of sphericity value was significant 
TABLE 4: Kaiser-Meyer-Olkin and Bartlett's test.

\begin{tabular}{lcccc}
\hline Test & $\begin{array}{c}\text { Approx. } \\
\text { chi-square }\end{array}$ & df & Sig. & KMO \\
\hline $\begin{array}{l}\text { Kaiser-Meyer-Olkin measure of } \\
\text { sampling adequacy }\end{array}$ & - & - & - & 0.765 \\
Bartlett's test of sphericity & 43470 & 1081 & 0.000 & \\
\hline
\end{tabular}

Approx, approximate; $d f$, degrees of freedom; KMO, Kaiser-Meyer-Olkin Index; Sig. significance.

\section{TABLE 5: Goodness of fit.}

\begin{tabular}{lcc}
\hline Chi-square & $d f$ & Sig. $(p)$ \\
\hline 12875.372 & 694 & 0.000 \\
\hline
\end{tabular}

$D f$, degrees of freedom; Sig., significance.

$(p<0.05)$, therefore factor analysis was appropriate to analyse the data. Only the first two components recorded eigenvalues above the threshold.

\section{Confirmatory factor analysis}

A series of Confirmatory Factor Analyses (CFA) were conducted on the data so as to validate the results of the data analysis. Confirmatory factor analysis is used in the advanced states of the research process to test the theory about latent processes or to test specific hypotheses (Pallant, 2007; Tabachnick \& Fidell, 2007).

\section{Chi-square $\left(\chi^{2}\right)$ test for model fit}

This is the primary fit index test mostly used in measurement models. If the associated $p$-value is not significant $(p>0.05)$, this means there is no significant difference between the sample variance and covariance matrix and the modelimplied variance and covariance matrix. Table 5 shows the goodness of fit.

The chi-square test results presented in Table 5 imply that the data fit the model well because it is showing a significant statistic $(p<0.05)$. The hypothesis that the research sought to explore was that employee motivation moderates the relationship between employee engagement and workplace surveillance. Table 6 indicates the regression weights for the three variables.

The full model showed that employee motivation has a positive significant relationship with employee engagement and a negative relationship with workplace surveillance. A series of CFA were conducted on the data to validate the results of the data analysis. CFA is used in the advanced states of the research process to test the theory about latent processes or to test specific hypotheses usually performed through SEM (Pallant, 2007; Tabachnick \& Fidell, 2007).

\section{Discussion}

The focus of the research was to analyse the moderating effect of employee motivation on the relationship that exists between employee engagement and workplace surveillance amongst employees at ZIMRA. A detailed discussion on the research constructs in this relationship was done taking into consideration previous literature.
TABLE 6: Regression weights - Employee motivation, surveillance and engagement.

\begin{tabular}{llcccc}
\hline Variable & & Estimate & SE & CR & $p$ \\
\hline Employee motivation & $\leftarrow$ Surveillance & 0.609 & 0.092 & 6.598 & $* * *$ \\
Employee engagement & $\leftarrow$ Employee motivation & 0.299 & 0.031 & 9.732 & $* * *$ \\
Employee engagement & $\leftarrow$ Surveillance & -0.483 & 0.054 & -8.85 & $* * *$ \\
\hline
\end{tabular}

$\mathrm{SE}$, Standard Estimate; CR, Coefficient of Variation.

***, shows significance.

The study found that employee motivation has a significant positive moderating impact on the relationship that exists between employee engagement and workplace surveillance. The findings of this study relate to previous research literature (Gawke et al., 2017; Rosenblat et al., 2014; Steinfeld, 2017). The reviewed literature concluded that if workplace surveillance is to maintain a positive relationship with employee engagement moderated by employee motivation, there is need for a management approach that embraces employees in making such surveillance decisions. Amongst other initiatives, the management approach can encompass consulting employees on all surveillance-related issues as opposed to dictating on such issues. The proffered literature shows that engaging employees when making decisions on workplace surveillance reduces the negative effect of surveillance on employee motivation and engagement. The similarity between the findings of this study and those of the reviewed literature shows that a motivated employee is an engaged employee who works harder for organisational success. The study found that employee engagement negatively relates to workplace surveillance, implying that the presence of workplace surveillance leads to employee disengagement; however, the study does not eliminate other factors that could have contributed to the negative relationship between these variables that were outside the scope of this article.

The study also sought to analyse if employee motivation positively relates to employee engagement. The research found that employee motivation and employee engagement positively relate to each other. This result is in agreement with previous literature (DeVaroa et al., 2017; Khan \& Iqbal, 2013; Mafini \& Dlodlo, 2014; Ruck et al., 2017; Vilnai-Yavetz \& Levina, 2018). The conclusion that employee motivation and employee engagement management can be done simultaneously is possible because a change in one variable positively affects the other.

The study also aimed to examine if workplace surveillance negatively relates to employee motivation. The study found that a positive relationship exists between employee motivation and workplace surveillance. Scarce literature supports this finding or the additional finding that when employees become aware that they are working under surveillance they derive motivation from that (Desprochers \& Roussos, 2001). These authors went on to add that employees derive motivation from knowing that surveillance provides an objective source of work performance, which is important in performance evaluation and rewards. However, much of the literature found a negative relationship between these two variables (Bakar, 2013; Cordella \& Cordella, 2017; 
Manzoor, 2012; Mohamed \& Maimunah, 2015; Moussa, 2015; Potoski \& Calley, 2018), noting that employees hate working under surveillance. Issues of worker's rights and workplace trust are some of the key issues raised as the reason why employees are demotivated by workplace surveillance.

\section{Practical implications of the study}

The study contributes to the existing body of knowledge regarding the moderating effect of employee motivation on the relationship between employee motivation and workplace surveillance. Considering the heavy presence of workplace surveillance, ZIMRA needs to invest in employee motivation because the study found that it is effective in moderating the relationship that exists between employee engagement and workplace surveillance. This result shows that management of employee motivation and employee engagement can be done at the same time, because a change in one variable positively affects the other. The results support the view that an engaged employee is a motivated employee, implying that ZIMRA management can simply invest much in one variable and the other variable will be positively affected. The research findings show that there is a need for ZIMRA to synchronise employee needs at work and the technology processes, to avoid a clash to the detriment of organisational interests. Employee buy-in is important in implementing workplace surveillance solutions to avoid a sabotage of the system by employees. ZIMRA needs to ensure that it does not frustrate its employees because of intensive use of workplace surveillance, considering that Zimbabwe's labour turnover is $19 \%$ as noted by Sibanda (2016).

\section{Limitations and recommendation for future study}

The research had notable limitations that need to be highlighted so that there is caution in applying these findings to the entire population in ZIMRA. The first limitation is that the study used only permanent employees of ZIMRA, who work at the border posts only. This excludes all other employees in many towns and urban areas, regardless of the fact that they work closely with ZIMRA border posts. Because of this limitation, there is a need to apply caution in generalising these findings to the entire population in ZIMRA.

In addition, data was collected using the SurveyMonkey method, and many organisations restrict SurveyMonkey messages from getting through to their corporate e-mail servers for security reasons. In addition, some targeted respondents did not have access to computers and the Internet, and this affected the research's response rate. Because of this, there must be caution in adopting this data collection method and generalising the result.

Workplace surveillance is a new concept in Zimbabwe and the concept has not received much research attention. This research focused on how employee motivation moderates the relationship between employee engagement and workplace surveillance. Similar research in Zimbabwe amongst other parastatals with a bigger sample size is an area worth researching to authenticate and/or verify the unique results that this study found, which went against vast amounts of literature.

Other variables interfere with how employee motivation moderates the relationship between employee engagement and workplace surveillance; however, this study did not look at those variables. These variables include but are not limited to remuneration, organisational culture and employee personality (Lemon \& Palenchar, 2018; Potoski \& Calley, 2018; Sibanda, 2016). Future research to ascertain how these variables moderate the relationship between the research constructs is critical.

\section{Conclusion}

The study contributes to the existing body of knowledge on the moderating effect of employee motivation on the relationship between employee engagement and workplace surveillance. The findings of the study depict that employee motivation has a positive significance on the relationship between employee engagement and workplace surveillance. There is a need for ZIMRA to involve employees in decisions that involve workplace surveillance to address employee engagement and employee motivation. There is a need for ZIMRA to invest in employee motivation through involving them in decisions that affect their work.

\section{Acknowledgements}

The authors acknowledge the support of all the respondents for taking part in the study.

\section{Competing interests}

The authors declare that they have no financial or personal relationships that may have inappropriately influenced them in writing this article.

\section{Authors' contributions}

F.T. collected and analysed the data. He was responsible for writing the first two drafts of this article. W.T.C. supervised F.T. for his doctoral studies. He also oversaw the data analysis and writing of the article.

\section{References}

Akafo, V., \& Boateng, P. A. (2015). Impact of reward and recognition on job satisfaction and motivation. European Journal of Business and Management, 7(24), 112-123. Allen, M. (2014). Employee engagement. Cambridge, UK: Cambridge University Press.

Allen, M. W., Walker, L. K., Coopman, S. J., \& Hart, J. L (2007). Workplace surveillance and managing privacy boundaries. Management Communication Quarterly, 21(2), 172-200. https://doi.org/10.1177/0893318907306033

Bakar, R. B. (2013). Understanding factors influencing employee engagement: A study of the financial sector in Malaysia. Doctoral dissertation. School of Management Business Portfolio: RMIT University.

Chang, J., \& Teng, C. (2017). Intrinsic or extrinsic motivations for hospitality employees' creativity: The moderating role of organisation-level regulatory focus. International Journal of Hospitality Management, 60(7), 133-141. https://doi. org/10.1016/j.ijhm.2016.10.003

Cordella, A., \& Cordella, T. (2017). Motivations, monitoring technologies, and pay for performance. Journal of Economic Behavior \& Organization, 133(7), 236-255. https://doi.org/10.1016/j.jebo.2016.10.016 
Cronbach, L. J., (1951). Coefficient alpha and the internal structure of tests. Psychometrika, 16(3), 297-334. https://doi.org/10.1007/BF02310555

Desprochers, S., \& Roussos, A. (2001). The jurisprudence of surveillance: A critical look at the laws of intimacy. Working Paper. Lex Electronica, 6(2), 23-43.

DeVaroa, J., Nan Maxwell, N., \& Morita, H. (2017). Training and intrinsic motivation in non-profit and for-profit organisations. Journal of Economic Behavio \&Organization, 139(20), 196-213. https://doi.org/10.1016/j.jebo.2017.04.005

Fuchs, C. (2013). Political economy and surveillance theory. Uppsala, Sweden: Uppsala University.

Gawke, J. C., Marjan, J., Gorgievski, M. J., \& Bakker, A. B. (2017). Employee entrepreneurship and work engagement: A latent change score approach. Journal of Vocational Behavior, 10(20), 88-100. https://doi.org/10.1016/j.jvb.2017.03.002

Hertzog, M. A. (2008). Considerations in determining sample size for pilot studies. Nursing and Health Journal, 1(31), 180-191.

Huni, S. (2016, January 03). Border posts crackdown. Ministerial team set up to curb smuggling. The Sunday News, p. 8

Kahn, W. A., (1990). Psychological conditions of personal engagement and disengagement at work. Academy of Management Journal, 33(4), 692-724.

Khan, W., \& Iqbal, Y. (2013). An investigation of the relationship between work motivation (intrinsic \& extrinsic) and employee engagement. Masters dissertation. Umea School of Business: Umea University.

Lackey, N. R., \& Wingate, A. L. (1998). The pilot study: One key to research success. Thousand Oaks, CA: Sage.

Lemon, L. L., \& Palenchar, M. J. (2018). Public relations and zones of engagement: Employees' lived experiences and the fundamental nature of employee engagement. Public Relations Review, 2(3),61-90. https://doi.org/10.1016/ j.pubrev.2018.01.002

Lopez-Valeiras, E., Gomez-Conde, J., \& Lunkes, R. J. (2017). Employee reactions to the use of management control systems in hospitals: Motivation vs threat. Business Horizons Journal, 12(9), 221-229.

Maduka, C. E., \& Okafor, O. (2014). Effect of motivation on employee productivity: A study of manufacturing companies in Nnewi. International Journal of Managerial Studies and Research, 2(7), 137-147.

Mafini, C. (2015). Predicting organisational performance through innovation, quality and inter-organisational systems: A public sector perspective. The Journal of Applied Business Research, 31(3), 939-952. https://doi.org/10.19030/jabr.v31i3.9227

Mafini, C., \& Dlodlo, N. (2014). The relationship between extrinsic motivation, job satisfaction and life satisfaction amongst employees in a public organisation. South African Journal of Industrial Psychology, 40(1), 1-13. https://doi.org/ 10.4102/sajip.v40i1.1166

Mafini, C., Surujlal, J., \& Dhurup, M. (2013). The relationship between job satisfaction and job loyalty among municipal sports officers. African Journal for Physical, Health Education, Recreation and Dance, 19(1), 12-29.

Manzoor, Q. (2012). Impact of employees motivation on organizational effectiveness. European Journal of Business and Management, 3(3), 36-44.

Mayer, C. H., Viviers, R., \& Tonelli, L. (2017). 'The fact that she just looked at me...' narrations on shame in South African workplaces. South African Journal of Industrial Psychology, 43(5), 1-10. https://doi.org/10.4102/sajip.v43i0.1385

Mohamed, S. A., \& Maimunah, A. (2015). The influence of perceived organizational support on employees' job performance. International Journal of Scientific and Research Publications, 5(4), 1-6.

Moussa, M. (2015). Monitoring employee behavior through the use of technology and issues of employee privacy in America. Sage Open, April-June, 1-13.

Muleya, T. (2014, July 17). NPA has potential to ease border challenges, features, opinion and analysis. The Herald, p. 5.

Mundia, V. (2014). Anti-corruption strategies of the Zimbabwe Revenue Authority (ZIMRA) customs department at Beitbridge border post: A case-based analysis. Unpublished Master's thesis, Faculty of Management Science, Stellenbosch Unpublished Master's the

Murongazvombo, P. K. (2015). Talent retention strategies in a competitive ICT industry: Case of twenty third century systems global (Zimbabwe). Unpublished Master's thesis, Graduate School of Business, Bindura University of Science Education, thesis, Gradua.

Ncube, N. (2016, April 17). ZIMRA intensifies fight against smuggling. The Sunday News, p. 7.

Nieswiadomy, R. M. (2002). Foundations of nursing research. London: Sage.

Pallant, J. (2007). SPSS survival manual (3rd edn.), Crows West, NSW: Open University Press.

Patsakis, C., Charemis, A., Papageorgiou, A., Mermigas, D., \& Pirounias, S. (2018). The market's response toward privacy and mass surveillance: The Snowden aftermath. Computers and Security Journal, 73(6), 194-206. https://doi.org/10.1016/ j.cose.2017.11.002

Potoski, M., \& Calley, P. J. (2018). Peer communication improves environmental employee engagement programs: Evidence from quasi-experimental field. Journal of Cleaner production, 172(9), 1486-1500. https://doi.org/10.1016/j.jclepro.2017.10.252
Rietzschel, E. F., Slijkhuis, M., \& Van Yperen, N. W. (2014). Close monitoring as a contextual stimulator: How need for structure affects the relation between close monitoring and work outcomes. European Journal of Work and Organizational Psychology, 23(3), 394-404. https://doi.org/10.1080/1359432X. 2012.752897

Rosenblat, A., Kneese, T., \& Danah, B. (2014). Workplace surveillance data \& society. Thousand Oaks, CA: Sage.

Ruck, K., Welch, M., \& Menara, B. (2017). Employee voice: An antecedent to organisational engagement? Public Relations Review, 43(2), 904-914. https://doi. org/10.1016/j.pubrev.2017.04.008

Ryan, J. C. (2017). Reflections on the conceptualization and operationalization of a set-theoretic approach to employee motivation and performance research. Journal of Innovation and Knowledge, 2(6), 45-47. https://doi.org/10.1016/ j.jik.2016.12.001

Saltson, E., \& Nsiah, S. (2015). The mediating and moderating effect of motivation in the relationship between perceived organisational support and employee job performance. International Journal of Economics, Commerce and Management, 3(7), 654-667.

Samaranayake, V., \& Gamage, C. (2012). A managerial incentive for workplace electronic surveillance. IADIS International Journal on Computer Science and Information Systems, 7(2), 87-100.

Sarwar, S., \& Abugre, J. (2013). The influence of rewards and job satisfaction on employees in the service industry. The Business \& Management Review, 3(2), 22-32.

Shaheen, A., \& Farooqi, Y. A. (2014). Relationship among employee motivation employee commitment, job involvement, employee engagement: A case study of University of Gujrat, Pakistan. International Journal of Multidisciplinary Sciences and Engineering, 5(9), 41-46. https://doi.org/10.1016/j.ijhm.2016.11.013

Shahzadi, I., Javed, A., Pirzada, S. S., Nasreen, S., \& Khanam, F. (2014). Impact of employee motivation on employee performance. European Journal of Business and Management, 6(23), 159-166.

Sibanda, F. (2016). Leveraging on training to enhance employee performance: A case of Zimbabwe Revenue Authority. Unpublished Master's thesis, Faculty of Social Sciences, Midlands State University, Zimbabwe.

Sibanda, P., Muchena, T., \& Ncube, F. (2014). Employee engagement and organisational performance in public sector organisations in Zimbabwe. International Journal of Asian Social Science, 4(1), 89-99.

Steinfeld, N. (2017). Track me, track me not: Support and consent to state and private sector surveillance. Telematics and Informatics Journal, 34(8), 1663-1672. https://doi.org/10.1016/j.tele.2017.07.012

Tabachnick, B. G., \& Fidell, L. S. (2007). Using multivariate statistics. Belmont, CA Wadsworth.

The Parliament of Zimbabwe. (2017). Employee engagement survey. Harare: Government Printers.

The World Bank. (2017). The World Bank's lending program in Zimbabwe. New York: World Bank and IFC.

Tomczak, D. L., Lanzo, L. A., \& Aguinis, H. (2018). Evidence-based recommendation for employee performance monitoring, Business Horizons Journal, 33(7), 1-9.

Townsm, D. M., \& Cobb, L. M. (2012). Notes on: GPS technology; employee monitoring enters a new era. Labor Law Journal, 63(6), 203-208.

Tsakanikas, V., \& Dagiuklas, T. (2017). Video surveillance systems: Current status and future trends. Computers and Electrical Engineering Journal, 22(1), 1-18.

Vilnai-Yavetz, I., \& Levina, O. (2018). Motivating social sharing of e-business content: Intrinsic motivation, extrinsic motivation, or crowding-out effect? Journal of Computers in Human Behavior, 79(5), 181-191.

Vinga, A. (2017, June 01). Lifestyle audits unsettle ZIMRA workers. The Financial Gazette, p. 5.

Yamani, Y. (1964). Statistics, an introduction analysis. New York: Harpen and Row Publishing Limited.

Yamoah, E. E. (2014). Monitoring employee performance at the workplace. Developing country studies. Albany, NY: State of New York University Press.

Yerby, J. (2013). Legal and ethical issues of employee monitoring. Online Journal of Applied Knowledge Management, 1(2), 44-55.

Zachary, M. K. (2013). Invasion of privacy: The moment of intrusion. Supervision, 74(4), 18-22.

Zameer, H., Ali, S., Nisar, W., \& Amir, M. (2014). The impact of the motivation on the employee's performance in beverage industry of Pakistan, International Journal of Academic Research in Accounting, Finance and Management Sciences, 4(1), 293-298.

ZIMRA. (2016). Revenue performance report for the year ending 31 December 2015. Harare: ZIMRA.

Zuboff, S. (2015). Big other: Surveillance capitalism and the prospects of an information civilization. Journal of Information Technology, 30(3), 75-89. https:// doi.org/10.1057/jit.2015.5 